ADBI Working Paper Series

\title{
EMPIRICAL ANALYSIS OF FACTORS
}

INFLUENCING PRICE OF SOLAR MODULES

Farhad Taghizadeh-Hesary,

Naoyuki Yoshino,

and Yugo Inagaki

No. 836

April 2018

\section{Asian Development Bank Institute}


Farhad Taghizadeh-Hesary is assistant professor of economics at the Faculty of Economics and Political Science of Waseda University, Tokyo. Naoyuki Yoshino is dean and chief executive officer of the Asian Development Bank Institute and professor emeritus of Keio University. Yugo Inagaki is an alumnus of Keio University.

The views expressed in this paper are the views of the author and do not necessarily reflect the views or policies of $A D B I, A D B$, its Board of Directors, or the governments they represent. ADBI does not guarantee the accuracy of the data included in this paper and accepts no responsibility for any consequences of their use. Terminology used may not necessarily be consistent with ADB official terms.

Working papers are subject to formal revision and correction before they are finalized and considered published.

The Working Paper series is a continuation of the formerly named Discussion Paper series; the numbering of the papers continued without interruption or change. ADBI's working papers reflect initial ideas on a topic and are posted online for discussion. Some working papers may develop into other forms of publication.

The Asian Development Bank recognizes "China" as the People's Republic of China and "Korea" as the Republic of Korea.

In this publication, "\$" refers to US dollars.

Suggested citation:

Taghizadeh-Hesary, F., N. Yoshino, and Y. Inagaki. 2018. Empirical Analysis of Factors Influencing Price of Solar Modules. ADBI Working Paper 836. Tokyo: Asian Development Bank Institute. Available: https://www.adb.org/publications/empirical-analysis-factorsinfluencing-price-solar-modules

Please contact the authors for information about this paper.

Email: farhad@aoni.waseda.jp

Asian Development Bank Institute

Kasumigaseki Building, 8th Floor

3-2-5 Kasumigaseki, Chiyoda-ku

Tokyo 100-6008, Japan

Tel: $\quad+81-3-3593-5500$

Fax: $\quad+81-3-3593-5571$

URL: $\quad$ www.adbi.org

E-mail: info@adbi.org

(C) 2018 Asian Development Bank Institute 


\begin{abstract}
The solar energy market has seen huge growth in recent years with a vast increase in solar cumulative capacity worldwide. One of the key drivers behind this growth is the decline in solar module prices. Thus, the price reduction mechanism in solar modules has become an important topic as the role of solar electricity in the overall energy supply and the market value of solar modules grow globally. Many empirical analyses have been carried out to unveil the mechanism behind this price reduction. However, the researches performed on the price reduction mechanism of solar modules over the years have focused purely on the technological aspect of the manufacturing. When analyzing price, the influence of economic factors such as interest rate and exchange rate must also be taken into consideration to achieve a precise analysis. In this paper, an oligopolistic model and econometric method are used to determine the economic factors that have an influence on solar module prices.
\end{abstract}

Keywords: solar modules, renewable energy, price reduction

JEL Classification: Q21, Q28, E43 


\section{Contents}

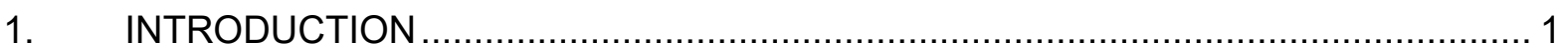

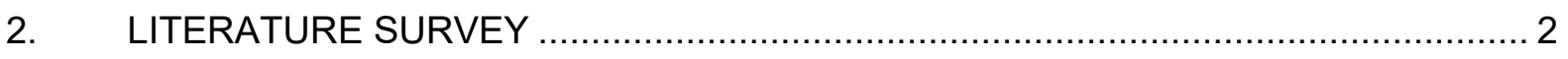

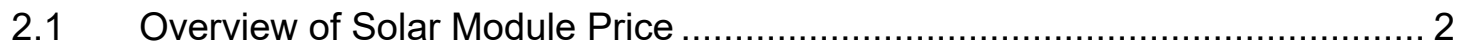

$2.2 \quad$ Price Reduction Mechanism ................................................................ 4

$2.3 \quad$ R\&D Expenditure in the Solar Industry ................................................. 5

$2.4 \quad$ Relationship between Oil Prices and Renewable Energy ............................. 5

2.5 Different Channels of Exchange Rate Influencing Solar Module Price ........... 7

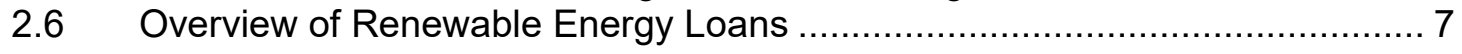

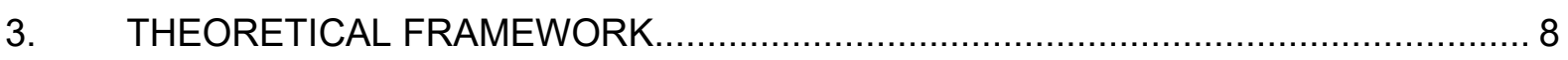

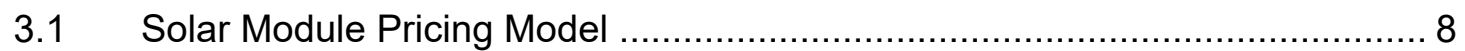

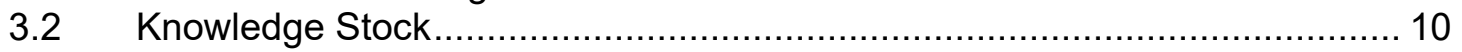

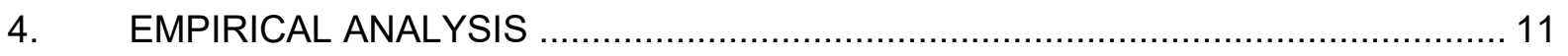

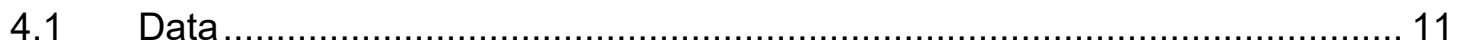

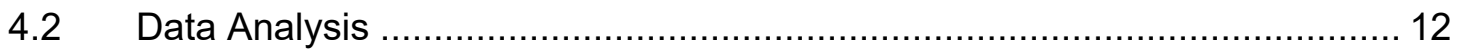

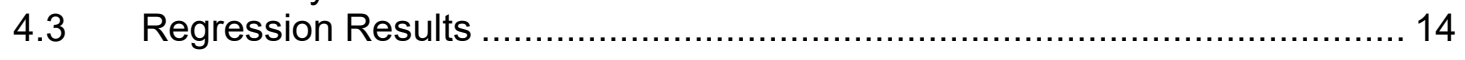

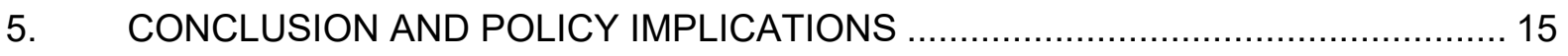

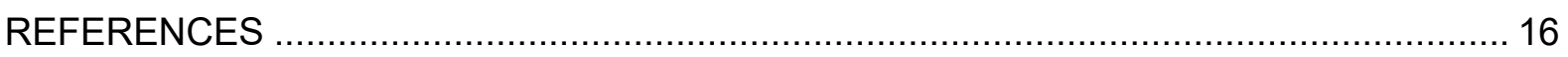




\section{INTRODUCTION}

Government and private sector incentives to invest in renewable energy have grown as a way of reducing fossil fuel dependency and environmental damage. Due to these new investments, the renewable energy field has seen vast growth in recent years. In the field of solar electricity in particular, the annual solar PV electricity production increased from 4 TWh in 2005 to 247 TWh in 2015 (IEA 2017). Moreover, the accumulated solar electricity plant capacity grew from 100,504 MW in 2012 to 368,000 MW in 2017 (Figure 1). One of the factors supporting this growth in the solar electricity sector is the reduction in the cost of solar modules.

Figure 1: Worldwide Growth in Cumulative Capacity of Solar Photovoltaics from 1992 to 2017

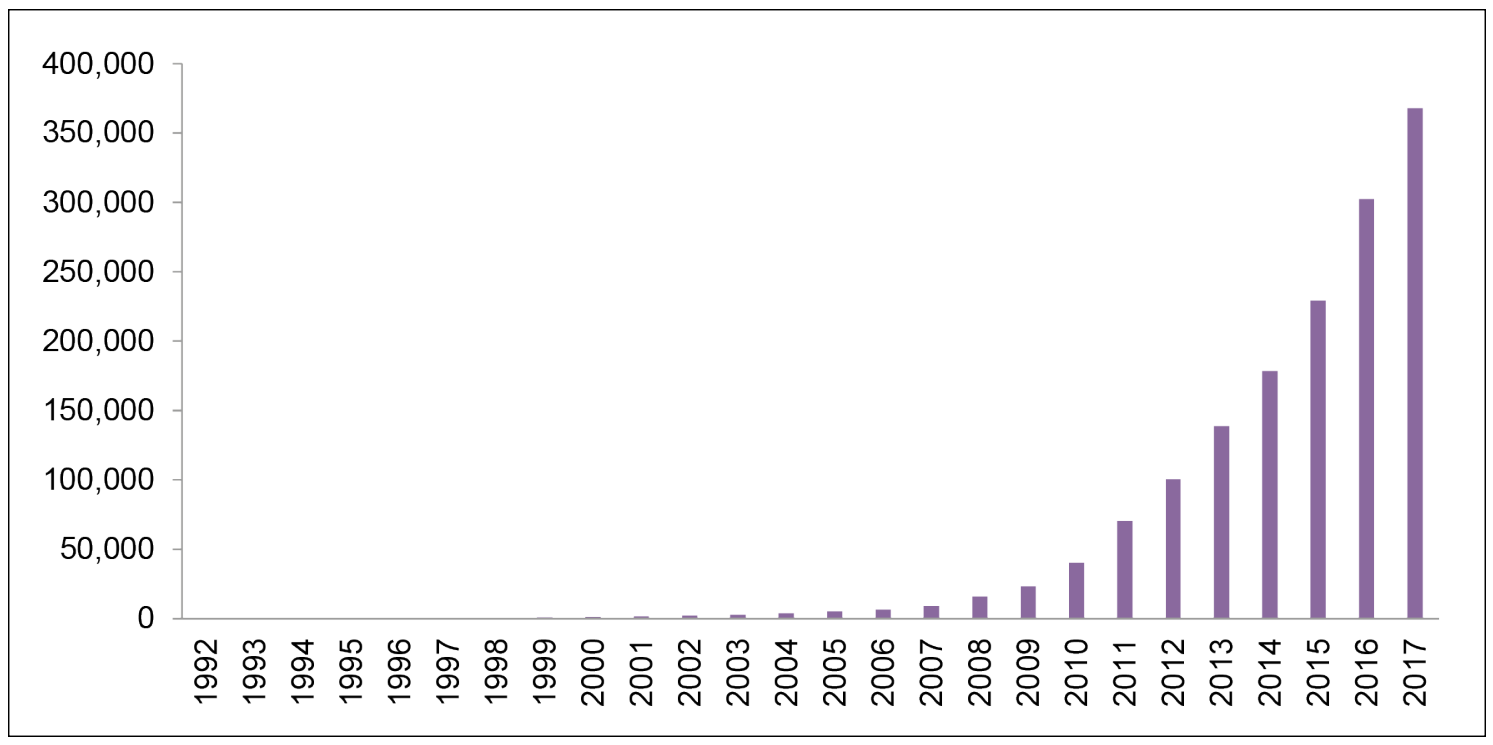

Note: Cumulative capacity of solar photovoltaics from 1992 to 2017 in MW. Created by writer using data collected from the Global Market Outlook for Solar Power 2016-2020, 2015-2019, 2014-2018 and Snapshot of Global PV 1992-2014.

Kimura and Zissler (2016) have carried out a comparison of solar PV prices in Japan and Germany. Their study analyzed solar PV system costs. Their comparison of solar PV cost ( $50 \mathrm{~kW}$ or more and less than $500 \mathrm{~kW})$ in 2015 showed that module cost makes up about $30 \%$ to $40 \%$ of the system price in Japan and $50 \%$ in Germany. Therefore, the price of solar modules plays a large part in solar system prices. As can be seen in Figure 2, the price of solar modules has seen a huge drop worldwide in recent years. The People's Republic of China (PRC), which dominates the solar module market today, saw a reduction from $\$ 5,810 / \mathrm{kW}$ in 2007 to $\$ 570 / \mathrm{kW}$ in 2015 and less than $\$ 350 / \mathrm{kW}$ in 2017 . However, a global comparison shows that there are differences in the speed of cost reduction. For example, Japan saw a drop from $\$ 3,700 / \mathrm{kW}$ in 2007 to $\$ 1,140 / \mathrm{kW}$ in 2015 . Here, the module price in Japan was initially cheaper than that in the PRC. However, in 2015, the module price in Japan was twice that of the PRC. To encourage the installation of solar electricity, analyzing the factors influencing the price reduction in solar photovoltaic modules is crucial. Although many researches have been carried out analyzing the price of solar modules, all have focused on the supply factor, especially the technological factors of the solar photovoltaic market price. Therefore, in this paper, we will consider the economic factors of the solar module market with a view to accurately identifying the factors 
behind price changes in solar modules. Section 2 discusses past researches related to potential factors influencing the solar module price reduction mechanism. The potential factors include learning by doing, R\&D expenditure, oil price, and exchange rate. Section 3 will clarify the process of creating our solar module pricing model, which includes wage, interest rate, exchange rate, R\&D expenditure, and oil price as explanatory variables, and module price as the independent variable. We will assume an oligopolistic market. Section 4 presents data analysis. Taking into consideration the results of the data analysis, fully modified OLS (FMOLS) will be conducted for regression. This will be followed by the empirical results on the relationship between solar module price, wage, interest rate, exchange rate, R\&D expenditure, and oil price. Section 5 presents a conclusion and policy implications. We will conclude that government efforts to increase financing channels and R\&D expenditures toward solar photovoltaics will be needed to accelerate solar system installation.

\section{LITERATURE SURVEY}

\subsection{Overview of Solar Module Price}

The solar module price changes in the five countries of the PRC, Germany, Japan, the Republic of Korea, and the United States are summarized in Figure 2. Overall, from 1992 to 2015, solar module prices decreased due to technological advances. By the early 2000s, the solar module price for the four countries of Germany, Japan, the Republic of Korea, and the United States had decreased to approximately $50 \%-70 \%$ since 1992. However, these four countries saw sudden increases in solar module price from 2004. This can be explained by the increase in crude oil prices. ${ }^{1}$ Figure 3 shows that crude oil prices started to rise in the early 2000s. With the increase in oil prices, the demand for alternative energy increased, and thus the price of solar modules. Moreover, in 2004, Germany saw a relatively sudden increase in solar module price from $\$ 3.7$ per watt in 2004 to $\$ 7.4$ per watt in 2005 . This can be explained by the revision of the feed-in tariff (FIT) policy. In 2004, Germany passed the German Renewable Energy Sources Act (EEG) 2004, which increased photovoltaic FIT price setting and made the policy applicable to solar PV systems larger than 1,000 MW (Ministry of the Environment 2015). This rise in solar FIT price setting and policy target expansion increased electricity suppliers' demand for renewable electricity equipment, resulting in the growth of annual solar PV installation from $0.14 \mathrm{GW}$ in 2003 to $0.67 \mathrm{GW}$ in 2004 (Figure 3). This increase in demand may account for the sudden increase in solar module price in Germany. Solar modules reverted to the declining trend from 2008 with solar module prices dropping to $\$ 3.5$ per watt in 2009 . This can be explained by another revision of the FIT in 2009 with the passing of EEG 2009. EEG 2009 announced that the FIT price degression rate would be increased and the price setting would be determined based on the annual solar PV installment in the previous year. This reduced the incentive for electricity suppliers to expand solar PV systems, thereby reducing both the demand for, and price of, solar modules. Japan introduced its FIT policy in 2012. This led to an increase in solar module installation from 2013. The annual solar PV installation more than quadrupled from $1.718 \mathrm{GW}$ in 2012 to $6.967 \mathrm{GW}$ in 2013. However, unlike in Germany under EEG 2004, the price of solar modules has continued to decrease in Japan since the introduction of the feed-in tariff. There are several possible explanations for this. First, the average price of crude oil started to decrease from 2012. In response, solar module prices have decreased due to the

\footnotetext{
1 For more information on the reasons behind the oil price increases in the 2000s see Taghizadeh-Hesary and Yoshino (2014) and Yoshino and Taghizadeh-Hesary (2014; 2015; 2016).
} 
energy substitution relationship between renewable energy and oil. Another reason is the difference in FIT policy management. The FIT policy in Japan is based on that of European countries such as Germany. With the precedent of Germany, it was not difficult to see that FIT overpricing led to excessive demand in solar modules and increases in both solar module prices and electricity prices. Therefore, the FIT levy for solar PV in Japan was set at 0.22 yen/kWh, lower than the levy under EGG 2004 of 0.51 eurocent/kWh (REI 2017). Therefore, the influence of FIT on solar module demand was smaller in Japan than in Germany.

Figure 2: Price Change in Solar Modules for the Top Five Producing Countries from 1992 to 2015

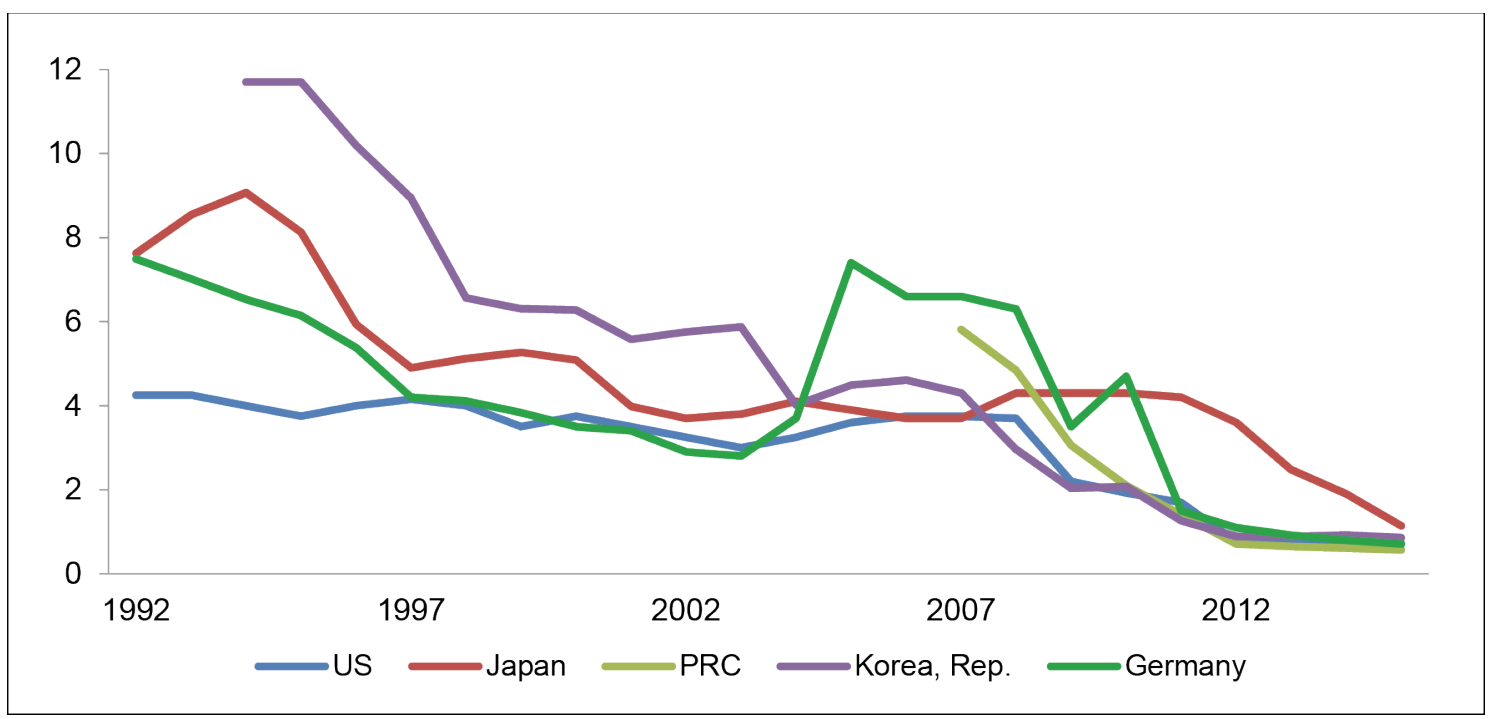

Note: Price of solar modules for top six solar module producing countries in watts. Country ranking of solar module production is computed using the solar module production data provided by the IEA-PVPS reports from 1997 to 2016. Price data for solar modules are also collected from the IEA-PVPS reports from 1997 to 2016 . The data for Malaysia, which was the fourth biggest solar module producer from 1997 to 2016, were not available.

Figure 3: Annual Solar Power Installation in Germany and Japan

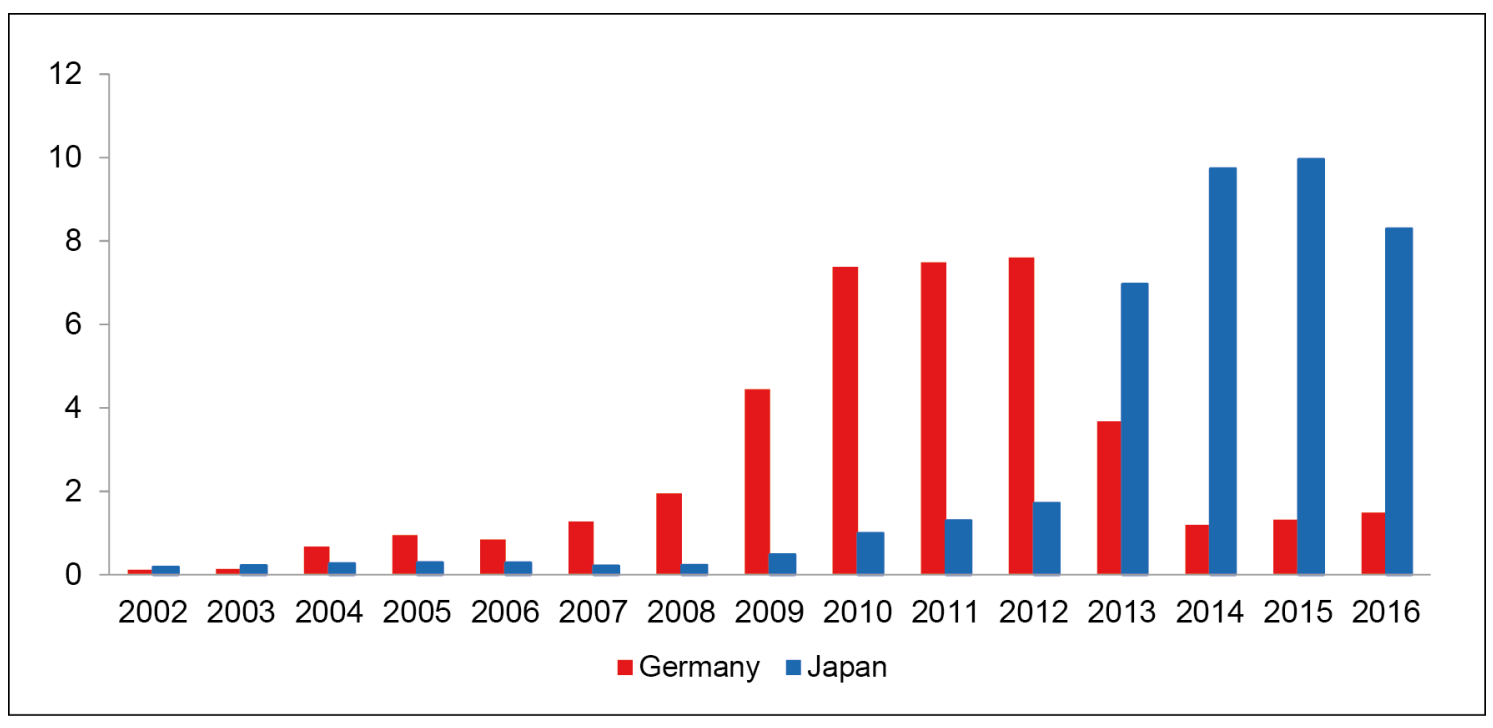

Note: Annual increase and decrease in net installed solar electricity generation capacity in Germany from 2002 to 2016 in GW. The data for Germany are retrieved from Fraunhofer and the data for Japan are retrieved from IRENA (2012). 


\subsection{Price Reduction Mechanism}

The analysis of solar electricity price reductions has always focused on the technological aspect of manufacturing, mainly the learning curve effect. The learning curve effect is a trend in manufacturing where the manufacturing process becomes more efficient as it produces more units Arrow (1962). Wright (1936) refers to this trend as the learning-by-doing effect. Neij, Anderson, and Durstewitz (1997) performed case studies on wind power and concluded that experience curves are applicable to energy conversion technologies such as solar PV. Many past researchers have created multiple models revolving around the learning curve to analyze solar module costs for the benefit of solar photovoltaic development. Messener (1998) created a learning curve model applicable to energy systems. Messener's model was created to analyze the influence of technological change. This model became the basis of learning curves in energy technology and was later extended to what is called the ERIS (Energy Research and Investment Strategy) model (Barreto et al. 2000). Pillai (2015) created a cost reduction model including cumulative capacity, plant size, polysilicon price, polysilicon usage, firm efficiency, PRC dummy, and investment as explanatory variables.

Some research has focused on the mechanism of the learning-by-doing effect. Bahk and Gort (1993) categorized learning by doing into three categories of labor, capital, and organization to explain the mechanism of learning by doing. Nemet (2005) came up with a solar module pricing model including various variables representing different learning-by-doing effect channels to pinpoint which processes of manufacturing show a learning-by-doing effect. McDonald and Schrattenholzer (2000) estimated the learning rates for various energy conversion technologies including solar photovoltaic modules using energy technology models.

As Glachant, Meniere, and Arnaud (2013) state in their paper, the experience curve effect plays a huge part in both the government's renewable energy policy discussions and solar PV manufacturing. However, there are researches questioning the validity of using learning by doing in empirical analysis. Nemet (2005) tackled the fundamental assumption that the learning-by-doing effect has a critical impact on the solar module cost reduction process. He used six cost reduction factors, i.e. module efficiency, plant size, yield, polycrystalline share, silicon consumption, and wafer size, to create a model of photovoltaic module price reduction. He concluded that learning by doing accounts for less than $10 \%$ of overall cost reduction. He went on to say that to make realistic decisions in the solar photovoltaic industry, knowledge spillovers and market dynamics must be considered. Similarly, Sallenave (1985) states in his paper that although learning curves can be useful for companies in competitive analysis, the learning curves do not serve as a reliable cost forecasting system because it is subject to many constraints. Schaeffer et al. (2004) state that the learning curve must be used with care as there are many data uncertainties in the energy sector.

The set of researches focusing on the technological aspect of price reduction has been the center of various renewable energy policies. However, the fundamental assumption that learning by doing should be included in energy technology prices may need to be reconsidered as production itself is a function of many different variables. As was mentioned in Nemet (2005), consideration of market dynamics may give new insights into the price reduction process. Taking this into account, this paper will add economic perspectives to the analysis of solar photovoltaic module price. In other words, the explanatory variables used in this paper will break down production into a function of several economic factors and market dynamics will be considered in the process of model production. 


\subsection{R\&D Expenditure in the Solar Industry}

R\&D expenditure in the solar energy sector has been growing globally. The global solar R\&D expenditure in 2016 totaled 3.6 billion dollars (Bloomberg 2017). To expand the installation of solar energy technologies, both the public sector and corporations have been increasing investment in solar R\&D. Under this trend, the influence of R\&D expenditure on technology price reduction has been an important topic. In solar module price researches, the effect of R\&D expenditure has been taken into consideration as an extension of learning-by-doing effect models to better understand the mechanism of cost reduction. There have been multiple solar module pricing models with R\&D expenditure as explanatory variable that are an extension of the ERIS model (Miketa and Schrattenholzer 2004; Barreto and Kypreos 2004). Glachant, Meniere, and Arnaud (2013) created an experience curve model using cumulative production, R\&D knowledge stock, and input price to predict module prices in 2020. Among the studies of renewable energy R\&D, there are also researches that focus on different types of R\&D in price analysis. Youah (2013) used different types of data set for R\&D expenditures to see which best fits the learning curve model. Youah compared the use of R\&D expenditure by itself and the accumulation of R\&D expenditure as explanatory variables to see which fits the trend in solar module price reduction better. The results showed that accumulation of R\&D expenditure was superior in identifying the price mechanism of solar modules. Hayamizu, Furubayashi, and Nakata (2014) compared the difference between the effect of public solar R\&D expenditure and corporate solar R\&D expenditure in Japan and concluded that the influence of corporate solar R\&D expenditure on solar module price is stronger than that of public solar R\&D expenditure. Although it is commonly assumed that R\&D expenditure results in cost reduction, recent research points out that $R \& D$ expenditure has limitations as a variable for price determination. Shimamoto, Ueta, and Kokubu (2017) performed an analysis on the use of R\&D expenditure in econometric analysis. R\&D expenditure does not always show results, therefore the use of R\&D expenditure as a variable to explain technological advances may give misleading results. In this case the use of patents as a variable may be an option as patents are direct results of R\&D. Patents, however, have specific purposes and converting them into a figure that considers the value of each patent in terms of the level of technological advances is still difficult. They also point out that the objective of R\&D expenditure varies and thus the influence of R\&D on technology price may be hard to identify just as patents. For example, in a country with stronger environmental regulations, R\&D expenditure may not result in an increased renewable energy technology price. Rather, expenditure on quality enhancement may increase the price of renewable energy technology. Taking this into account, technological advancement does not always lead to price reduction or the market superiority that comes with it.

\subsection{Relationship between Oil Prices and Renewable Energy}

Renewable energy was developed as a substitute for oil. The transition from oil-based energy to renewable energy was backed up by an increase in oil price and a global trend toward a sustainable society. Figure 4 summarizes the oil price changes from 1990 to 2015. Ever since 2002, the world has seen sudden increases in oil prices. As oil prices have increased, the demand for alternative energy has also increased. Therefore, in renewable price analysis, the influence of oil prices cannot be ignored, which is the so-called "primary" or "substitution effect." There is also a secondary effect of oil on the price of PV. Oil or energy is considered a production input alongside labor and capital. When the price of oil or energy rises, the production cost will increase, 
which pushes the price of PV upward. ${ }^{2}$ An empirical study by Brunnschweiler (2009) backs this up. The results show that an increase in oil price has a positive influence on renewable energy consumption. Papandreou and Ruzzenenti (2015) performed an analysis of the influence that fossil fuel price has on low carbon energy systems. Their discussion suggests that maintaining oil price played a role in smoothing the transition to a sustainable energy system. Cheon and Urpelainen (2012) carried out an empirical analysis on the influence oil price has on technological advances in renewable energy. The analysis shows that an increase in oil prices results in the increase of factors such as public renewable R\&D expenditure and renewable patents. Similar results can be found from a work by Wong, Chia, and Chang. (2013). They conducted an analysis on the elasticity of energy R\&D in relation to changes in oil prices. Their results showed that oil price has positive correlations to renewable R\&D. Therefore, increases in oil prices may accelerate technological advances. As noted in Section 2.2, increases in R\&D are commonly known to lower prices of renewable technologies. Therefore, an increase in oil price will increase R\&D expenditure and in turn lower the price of solar modules. However, the impact that lower oil prices have on renewable energy technologies depends on the scale and location of the project (Terrado, Mendis, and Fitzgerald 1988).

Figure 4: Daily Change in Crude Oil Price from 2 January 2005 to 30 December 2017

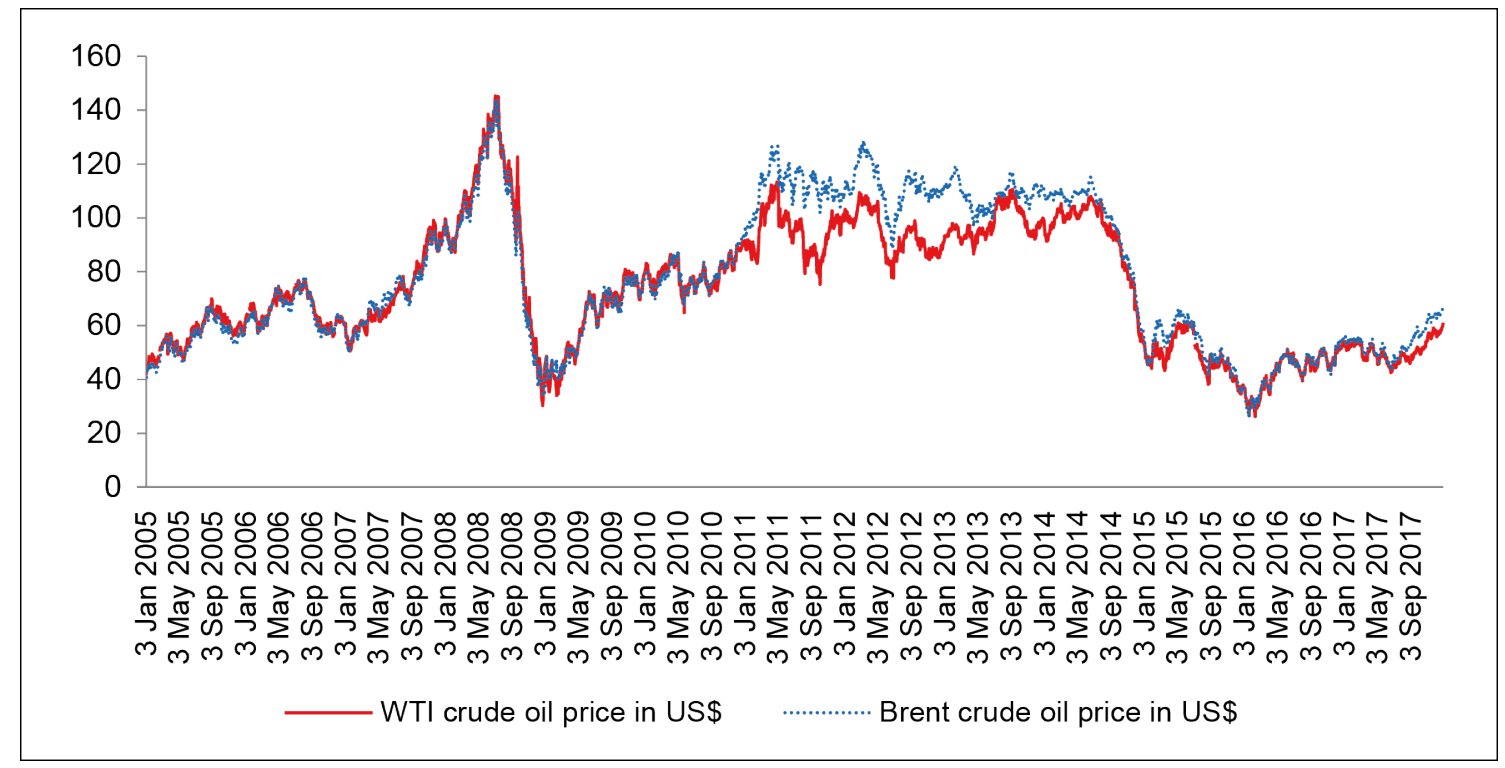

Note: WTI crude oil price is West Texas Intermediate, Cushing, Oklahoma Spot Price, Free on Board (US\$ per barrel). Brent crude oil price is Europe Brent Spot Price FOB (Dollars per Barrel). Source: Thomson Reuters, available at: http://www.eia.gov/dnav/pet/pet_pri_spt_s1_d.htm (accessed 12 February 2018)

2 Oil prices have both macroeconomic and firm-level impacts. For more information about the impact of oil prices on macroeconomic variables see Taghizadeh-Hesary and Yoshino (2015) and TaghizadehHesary et al. $(2013,2016)$, and for more information about the mechanisms of the transmission of oil prices at micro level (households and firms) see: Taghizadeh-Hesary and Yoshino (2016); TaghizadehHesary et. al $(2016 ; 2017)$. 


\subsection{Different Channels of Exchange Rate Influencing Solar Module Price}

There are two main channels through which the exchange rate has an influence on solar module price: material imports and oil imports. First, through the importation of solar module materials, the manufacturing cost of solar modules is influenced by the exchange rate. The raw material of a solar module is polysilicon. Polysilicon is first processed into silicon ingots, which are then sliced into silicon wafers. These silicon wafers are integrated into solar cells, which function as the fundamental energy conversion units. Finally, the solar cells are put together into solar modules. In the process of manufacturing solar modules, there are two main international transactions to be noted, i.e. the importation of solar cells and silicon (Figure 5). There have been precedent works on the influence of the material cost on solar module prices. Nemet (2005) used a model with polysilicon as an independent variable and solar module price as the dependent variable. The results showed that silicon cost explains about $12 \%$ of the learning-by-doing effect. Similarly, an empirical analysis by Pillai (2014) showed that a $1 \%$ drop in silicon price accounts for a $0.9 \%$ drop in solar module prices. Therefore, both the price of materials and the strength of each country's national currency, which influences the material import costs, have an influence on solar module price. The second channel is through the changes in oil import prices. The technological advancement in renewable energy has been backed up by the price increase in crude oil and the global trend toward a sustainable society. Therefore, the exchange rate will also influence solar modules indirectly by influencing oil price.

Figure 5: Solar Module Manufacturing Process

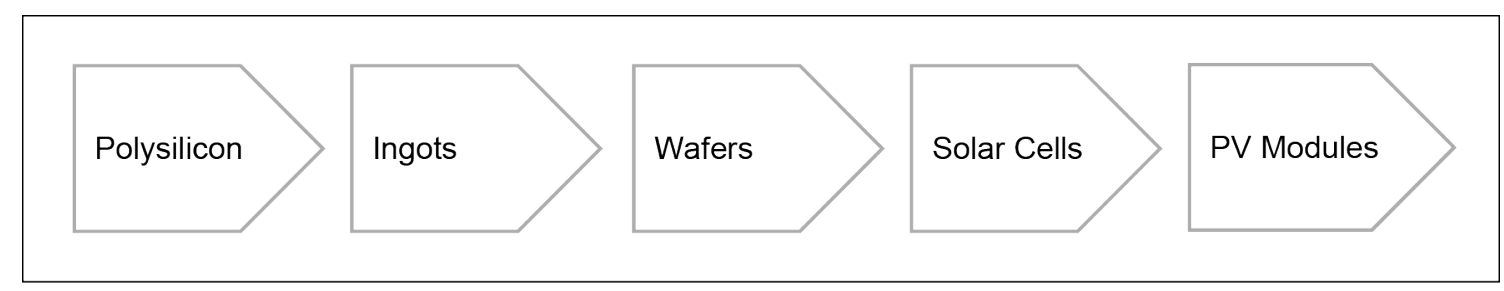

Note: Manufacturing process of solar modules from raw material of polysilicon to solar photovoltaic modules.

\subsection{Overview of Renewable Energy Loans}

The renewable energy industry is considered high-tech and capital-intensive as it takes time to recoup investment. The influence of interest rate on renewable technology development has been discussed in past researches. A discussion note by the Council on Economic Policies (CEP) analyzes the influence of low interest on renewable energy technology (Monnin 2015). Monnin states that long-term interest rates play an important role in energy investments. His analysis showed that the impact of changes in interest rate is stronger on green energy technology costs than on brown energy costs. Therefore, the interest rate not only influences renewable energy technology cost but the relative competitiveness between green and brown technology. Similarly, research by Brunnschweiler (2009) shows that development in the financing sector has a significant impact on renewable technology development. The research included an empirical analysis on the relationship between financial sector development measures and renewable energy sector development. 


\section{THEORETICAL FRAMEWORK}

\subsection{Solar Module Pricing Model}

We constructed a solar module pricing model using the following procedure. We assume the production function for solar module producer countries takes the form of the Cobb-Douglas production function with five production inputs, where $\left(\mathrm{y}_{\mathrm{t}}\right)$ is the total production of solar modules, $\left(\mathrm{A}_{t}\right)$ is the productivity parameter, $\left(\mathrm{N}_{t}\right)$ is labor input, $\left(\mathrm{K}_{t}\right)$ is capital stock, and $\left(\mathrm{IM}_{t}\right)$ is imports. $(\alpha),(\beta)$, and $(\gamma)$ are the output elasticities of labor input, capital stock, and imports:

$$
y_{t}=A_{t} N_{t}^{\alpha} K_{t}^{\beta} I M_{t}^{\gamma}=f(A, N, K, I M)
$$

The assumed inverse demand curve is shown in Eq. 2, where $\left(\mathrm{p}_{\text {solar, }, t}\right)$ is the price of solar modules followed by the intercept $(\bar{B})$, coefficients $\left(d_{1}\right)$ and $\left(d_{2}\right)$, the price of oil in US dollars $\left(p_{o i l, t}\right)$, and the exchange rate $\left(e_{t}\right)$. Here, the import price of oil is considered because renewable energy technology functions as a substitute for oil resources. Thus, if the import price for oil rises, the demand for solar modules will increase and the price of solar modules will rise.

$$
p_{\text {solar }, t}=\bar{B}-d_{1} y_{t}+d_{2} p_{o i l, t} e_{t}
$$

The cost function assumed for solar modules is shown in Eq. 3. $\left(\mathrm{C}_{t}\right)$ is the cost of solar module production, $\left(\mathrm{w}_{t}\right)$ is the labor cost, $\left(\mathrm{r}_{t}\right)$ is the interest rate, and $\left(\mathrm{e}_{t}\right)$ is the exchange rate. Here, cost is the sum of labor cost, capital cost, and import cost.

$$
C_{t}=w_{t} N_{t}+i_{t} K_{t}+e_{t} I M_{t}
$$

We assume the solar energy industry is an oligopolistic market. Therefore, cost is minimized through the Lagrange multiplier to maximize profit. The profit equation for a solar module producer is shown in Eq. 4 with production function as the constraint equation in Eq. 5.

$$
\begin{aligned}
& \operatorname{MinC}_{t}=w_{t} N_{t}+r_{t} K_{t}+e_{t} I M_{t} \\
& \text { subject to } y=A_{t} N_{t}^{\alpha} K_{t}^{\beta} I M_{t}^{\gamma}=f(A, N, K, I M)
\end{aligned}
$$

The Lagrange function is defined as Eq. 6 . Eqs 7 to 10 are the first order conditions for the cost minimization problem.

$$
\begin{aligned}
& L_{t}=w_{t} N_{t}+r_{t} K_{t}+e_{t} I M_{t}+\lambda(y-f(A, N, K, I M)) \\
& \frac{\partial L}{\partial N}=w-\lambda \frac{\partial f}{\partial N}=0 \\
& \frac{\partial L}{\partial K}=r-\lambda \frac{\partial f}{\partial K}=0 \\
& \frac{\partial L}{\partial I M}=e-\lambda \frac{\partial f}{\partial I M}=0
\end{aligned}
$$




$$
\frac{\partial L}{\partial \lambda}=y-f(A, N, K, I M)=0
$$

By differentiating $f$ with respect to $\mathrm{N}, \mathrm{K}$, and IM using Eq. 1, we gain the following equations, Eq. 11 to Eq. 13.

$$
\begin{aligned}
& \frac{\partial f}{\partial N}=\alpha \frac{y}{N} \\
& \frac{\partial f}{\partial K}=\beta \frac{y}{K} \\
& \frac{\partial f}{\partial I M}=\gamma \frac{y}{I M}
\end{aligned}
$$

Using Eq. 7 to Eq. 10 and Eq. 11 to Eq. 13, N, K, and IM can be expressed as below in equations Eq. 14 to Eq. 16.

$$
\begin{aligned}
& \frac{\partial L}{\partial N}=w-\alpha \lambda \frac{y}{N}=0 \\
& \leftrightarrow \mathrm{N}=\alpha \lambda \frac{y}{w} \\
& \frac{\partial L}{\partial K}=r-\beta \lambda \frac{y}{K}=0 \\
& \leftrightarrow \mathrm{K}=\beta \lambda \frac{y}{r} \\
& \frac{\partial L}{\partial I M}=e-\lambda \frac{y}{I M}=0 \\
& \leftrightarrow \mathrm{IM}=\gamma \lambda \frac{y}{e}
\end{aligned}
$$

Using Eqs 14 to 16, cost function (Eq. 3) and marginal cost can be written as below.

$$
\begin{aligned}
& \mathrm{C}=w\left(\alpha \lambda \frac{y}{w}\right)+r\left(\beta \lambda \frac{y}{r}\right)+e\left(\gamma \lambda \frac{y}{e}\right)=\mathrm{C}(w, r, e, y) \\
& \text { Marginal Cost: } \frac{\partial C}{\partial y}=\lambda(w, r, e, y)
\end{aligned}
$$

The profit of a solar module producer company can be expressed as Eq. 19. By taking partial derivative of profit with respect to solar module production $\left(\mathrm{y}_{\mathrm{t}}\right)$, the optimal output at which profit is maximized can be computed. As shown in Eq. 20, under an oligopolistic market, profit is maximized when marginal revenue equals marginal cost. Thus, using Eq. 16 and Eq. 18, the optimal production of solar modules $\left(\mathrm{y}_{\mathrm{t}}\right)$ is Eq. 21.

$$
\begin{aligned}
\pi & =p_{\text {solar }} y-C(w, r, e, y) \\
& =\left(\bar{B}-d_{1} y+d_{2} p_{o i l} e\right) * y-C(w, r, e, y)
\end{aligned}
$$




$$
\begin{aligned}
& \frac{\partial \pi}{\partial y}=(\text { Marginal Revenue })-(\text { Marginal Cost })=0 \\
& \bar{B}-2 d_{1} y+d_{2} p_{\text {oil }} e-\lambda=0 \\
& \leftrightarrow \mathrm{y}=\frac{1}{2 d_{1}}\left(\bar{B}+d_{2} p_{\text {oil }} e-\lambda\right)
\end{aligned}
$$

Using Eq. 21, Eq. 2 can be rewritten as below.

$$
p_{\text {solar }}=\bar{B}-\frac{1}{2}\left(\bar{B}+d_{2} p_{\text {oil }} e-\lambda\right)=\frac{1}{2}\left(\bar{B}-d_{2} p_{\text {oil }} e+\lambda\right)
$$

As shown in Eq. 18, $\lambda$ is a function of wage $\left(\mathrm{w}_{t}\right)$, interest rate $\left(\mathrm{r}_{t}\right)$, exchange rate $\left(\mathrm{e}_{t}\right)$, and production of solar modules $\left(\mathrm{y}_{\mathrm{t}}\right)$. Therefore, using Eq. 22, we understand that price of solar modules $\left(p_{\text {solar, }}\right)$ is a function of wage $\left(\mathrm{w}_{t}\right)$, interest rate $\left(\mathrm{r}_{t}\right)$, exchange rate $\left(\mathrm{e}_{t}\right)$, and price of oil $\left(p_{o i l, t}\right)$.

$$
p_{\text {solar }}=\frac{1}{2}\left(\bar{B}-d_{2} p_{\text {oil }} e+\lambda(w, r, e, y)\right)=g\left(w, r, e, y, p_{\text {oil }}\right)
$$

From the results, the pricing model for solar modules can be written as below:

$$
\log \left(p_{\text {solar }, t}\right)=p_{0}+p_{1}\left(r_{t}\right)+p_{2} \log \left(p_{\text {oil }, t}\right)+p_{3} \log \left(e_{t}\right)+p_{4} \log \left(A_{t}\right)+\varepsilon_{t}
$$

Econometric analysis will be conducted using this pricing model. We will compute the coefficients and analyze which factors have a significant influence on the price of solar photovoltaic modules.

\subsection{Knowledge Stock}

In this research, we define productivity parameter $\mathrm{A}_{t}$ as the accumulation of research and development expenditure. $A_{t}$ is defined as below:

$$
A_{t}=(1-\delta) A_{t-1}+R D_{t}
$$

This is based on the study by Youah (2013), which indicated that accumulation of R\&D expenditure is more appropriate in analyzing solar module prices. Here, $R D_{t}$ is the R\&D expenditure by a country on photovoltaic technology and $\delta$ is the depreciation rate of $R \& D$ expenditure. In this research, it is assumed that the effect of R\&D expenditure will fade as time passes at depreciation rate $\delta$. For simplification, I assume the depreciation of knowledge stock $\delta$ is fixed across countries and terms.

Nemet and Arnulf (2012) reviewed different knowledge depreciation rates in energy technology and pointed out that there have been few studies on the knowledge stock depreciation rate in the field of solar industries. One important research to be noted is the research by Watanabe, Nagamatsu, and Griffy-Brown (2003). They computed that the mean knowledge stock annual depreciation rate in the Japanese solar industry is approximately $30 \%$. Following this result, the basic depreciation rate is set at $30 \%$ in the analysis. 


\section{EMPIRICAL ANALYSIS}

\subsection{Data}

Analysis was conducted on the top five solar module producing countries in the world from 1997 to 2015. The five countries are the PRC, Germany, Japan, the Republic of Korea, and Malaysia (Figure 6). However, due to the lack of statistics available on Malaysia, the analysis was conducted on the sixth solar module producing country, the United States. Annual data from 1992 to 2015 were used for the analysis of Germany, Japan, and the United States. Due to a lack of data, quarterly data from 2007Q4 to 2015Q4 were used for the PRC and annual data from 1993 to 2015 were used for the Republic of Korea.

\section{Figure 6: Share of Total Solar Module Production from 1997 to 2015}

$(\%)$

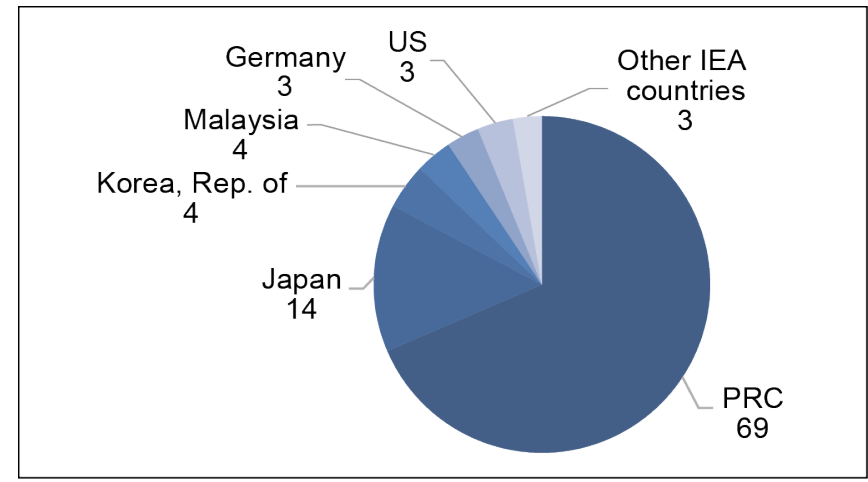

Note: Share of total solar module production from 1997 to 2015 . Created by the writer using data from IEA-PVPS reports from 1998 to 2016. Share is computed based on total solar module production in watts. Data on total solar module production from 1992 to 1996 are excluded because figures by country were not available. The individual percentages of solar module production for other IEA countries are less than $1 \%$.

For price, we used the solar module prices collected from the IEA-PVPS and Bloomberg databases. For wage, we used the average hourly earnings index $(2010=100)$ in the manufacturing sector collected from the OECD database. As the index was not available for the PRC, average wage taken from the Federal Reserve Bank of Atlanta was used instead. These data will be converted into index form $(2010=100)$ just like wage data for other countries. For interest rate, we used the 10 -year government bond yield rate collected from the OECD database and Bloomberg. For exchange rate, we used the real effective exchange rate $(2010=100)$ collected from Bruegel (2017) and the World Bank database. For R\&D expenditure, we used the government R\&D budget data collected from IEA-PVPS and Bloomberg. It should be noted that R\&D expenditure data, including corporate R\&D, were available. However, we used the government budget instead as the coverage of corporations is limited. Quarterly data for R\&D expenditure were not available for the PRC. Therefore, we assumed that annual R\&D expenditure was made on a quarterly basis equally and divided the annual R\&D expenditure by four. Knowledge stock was computed using the new quarterly figures and quarterly adjusted depreciation rate. For the price of oil, we used the simple average of Brent crude oil prices, Dubai crude oil prices, and West Texas Intermediate (WTI) crude oil prices available from the World Bank database. The data used for solar modules, R\&D expenditure, and oil prices are in nominal US dollars. The three series are all deflated by the US GDP deflator $(2010=100)$. The 
data for wage are based on national currencies. Wage and long-term interest rate are deflated using the national GDP deflator $(2010=100)$. The GDP deflators for all countries were collected from the World Bank database.

\subsection{Data Analysis}

\subsubsection{Unit Root Test}

All series must be evaluated for stationarities, as the use of stationary series in regression analysis will have spurious results. We performed the augmented DickyFuller test in level to check for unit roots. Excluding interest rate, all series were tested in their logarithm form. The results are summarized in Table 1. For all series among five countries, the null hypothesis was not rejected in level. Therefore, we had to conduct a unit root test on first differences of all series. The results showed that the null hypothesis was rejected in the first difference. This means that all series have unit roots in the first differences. Once the test had been conducted and it was discovered that the series are nonstationary in level and stationary in first differences, they were integrated of order one or I (1). Therefore, all series were integrated of order one. Since all the series share the same order of integration, a cointegration test had to be conducted between all series.

Table 1: Unit Root Test (Augmented Dickey-Fuller Test)

\begin{tabular}{|c|c|c|c|c|c|}
\hline \multirow[b]{3}{*}{ Country } & \multirow[b]{3}{*}{ Variable } & \multicolumn{4}{|c|}{ Augmented Dickey-Fuller Test (ADF) } \\
\hline & & \multicolumn{2}{|c|}{ Levels } & \multicolumn{2}{|c|}{ First Differences } \\
\hline & & t-statistics & p-value & t-statistics & p-value \\
\hline \multirow[t]{5}{*}{ Germany } & $\mathrm{p}_{\text {solar }}$ & -0.011 & 0.948 & $-4.697^{\star *}$ & $0.001^{* *}$ \\
\hline & w & -2.126 & 0.237 & $-3.952^{* *}$ & $0.007^{* *}$ \\
\hline & r & 0.544 & 0.984 & $-5.645^{\star *}$ & $0.000^{* *}$ \\
\hline & $\mathrm{e}$ & -1.897 & 0.328 & $-3.774^{* *}$ & $0.010^{* *}$ \\
\hline & $A$ & -2.252 & 0.195 & $-4.653^{* *}$ & $0.002^{* *}$ \\
\hline \multirow[t]{5}{*}{ Japan } & $\mathrm{p}_{\text {solar }}$ & 1.375 & 0.998 & $-3.339^{*}$ & $0.025^{*}$ \\
\hline & w & -1.396 & 0.566 & $-4.031^{* *}$ & $0.006^{* *}$ \\
\hline & $\mathrm{r}$ & 0.179 & 0.965 & $-3.964^{* *}$ & $0.007^{* *}$ \\
\hline & $\mathrm{e}$ & -1.802 & 0.370 & $-3.485^{\star}$ & $0.019^{*}$ \\
\hline & $A$ & -2.600 & 0.110 & $-3.068^{* *}$ & $0.046^{* *}$ \\
\hline \multirow[t]{5}{*}{ Korea, Rep. of } & $\mathrm{p}_{\text {solar }}$ & 0.127 & 0.960 & $-4.283^{\star *}$ & $0.004^{* *}$ \\
\hline & w & -1.219 & 0.648 & $-4.867^{* *}$ & $0.001^{* *}$ \\
\hline & $r$ & -2.936 & 0.057 & $-7.310^{* *}$ & $0.000^{* *}$ \\
\hline & e & -0.274 & 0.915 & $-4.923^{* *}$ & $0.001^{* *}$ \\
\hline & $A$ & -0.278 & 0.915 & $-5.289^{* *}$ & $0.000^{* *}$ \\
\hline \multirow[t]{5}{*}{ PRC } & $\mathrm{p}_{\text {solar }}$ & -1.623 & 0.459 & $-3.651^{* *}$ & $0.010^{* *}$ \\
\hline & W & -0.481 & 0.879 & $-4.048^{* *}$ & $0.005^{\star *}$ \\
\hline & $\mathrm{R}$ & -0.610 & 0.851 & $-4.139^{* *}$ & $0.004^{* *}$ \\
\hline & $E$ & -0.155 & 0.934 & $-4.507^{\star \star}$ & $0.001^{* *}$ \\
\hline & $A$ & -0.499 & 0.877 & $-4.151^{* *}$ & $0.003^{* *}$ \\
\hline \multirow[t]{5}{*}{ US } & $\mathrm{p}_{\text {solar }}$ & 0.773 & 0.991 & $-4.549^{* *}$ & $0.002^{* *}$ \\
\hline & w & -1.827 & 0.358 & $-3.375^{*}$ & $0.024^{*}$ \\
\hline & $r$ & -1.221 & 0.647 & $-5.949^{* *}$ & $0.000^{* *}$ \\
\hline & e & -2.771 & 0.080 & $-3.434^{*}$ & $0.020^{*}$ \\
\hline & A & -1.363 & 0.582 & $-3.805^{\star *}$ & $0.009^{* *}$ \\
\hline \multirow[t]{2}{*}{ World } & $\mathrm{p}_{\mathrm{oil}}$ & -1.219 & 0.649 & $-4.147^{* *}$ & $0.004^{* *}$ \\
\hline & $\mathrm{p}_{\text {oil }}$ (quarterly) & -0.982 & 0.748 & $-4.292^{* *}$ & $0.002^{* *}$ \\
\hline
\end{tabular}

Note: ${ }^{*}$ denotes significance at the $5 \%$ level and ${ }^{* *}$ denotes significance at the $1 \%$ level. 


\subsubsection{Cointegration Test}

To identify the cointegrating vectors among the five series, i.e. price, interest rate, exchange rate, wage, and knowledge stock, we conducted a cointegration analysis using the Johansen test. Again, the test was conducted on their logarithm form except for interest rate. The results are summarized in Table 2 and show that the null hypothesis was rejected. This means that all series for each country have at least one cointegrating equation. In other words, all series are cointegrated and there is a long-run association among price (in logarithm), interest rate, exchange rate (in logarithm), wage (in logarithm), and knowledge stock (in logarithm). When there are cointegrations, an error correction model should be used for the regression analysis. As all the variables for this research are I(1), we consider the fully modified OLS introduced by Phillips and Hansen (1990). This model allows us to provide optimal estimates of cointegrating regressions.

Table 2: Cointegration Test

\begin{tabular}{|c|c|c|c|c|c|c|}
\hline \multirow[b]{2}{*}{ Country } & \multirow[b]{2}{*}{$\begin{array}{c}\text { Hypothesized } \\
\text { No. of CE(s) }\end{array}$} & \multirow[b]{2}{*}{ Eigenvalue } & \multicolumn{2}{|c|}{ Trace } & \multicolumn{2}{|c|}{ Maximum Eigenvalue } \\
\hline & & & $\begin{array}{c}\text { Trace } \\
\text { Statistic }\end{array}$ & Prob. & $\begin{array}{c}\text { Max-Eigen } \\
\text { Statistic }\end{array}$ & Prob. \\
\hline \multirow[t]{6}{*}{ Germany } & $r=0$ & 0.879 & 134.253 & $0.000^{* \star}$ & 46.539 & $0.008^{* *}$ \\
\hline & $r<=1$ & 0.816 & 87.714 & $0.001^{* *}$ & 37.240 & $0.019^{*}$ \\
\hline & $r<=2$ & 0.719 & 50.474 & $0.028^{*}$ & 27.917 & $0.045^{*}$ \\
\hline & $r<=3$ & 0.456 & 22.557 & 0.269 & 13.374 & 0.418 \\
\hline & $r<=4$ & 0.277 & 9.183 & 0.349 & 7.139 & 0.473 \\
\hline & $r<=5$ & 0.089 & 2.044 & 0.153 & 2.044 & 0.153 \\
\hline \multirow[t]{6}{*}{ Japan } & $r=0$ & 0.929 & 144.866 & $0.000^{* *}$ & 58.084 & $0.000^{* *}$ \\
\hline & $r<=1$ & 0.810 & 86.782 & $0.001^{* *}$ & 36.537 & $0.024^{*}$ \\
\hline & $r<=2$ & 0.768 & 50.245 & $0.029^{*}$ & 32.108 & $0.012^{*}$ \\
\hline & $r<=3$ & 0.378 & 18.137 & 0.556 & 10.434 & 0.703 \\
\hline & $r<=4$ & 0.281 & 7.703 & 0.498 & 7.251 & 0.460 \\
\hline & $r<=5$ & 0.020 & 0.452 & 0.502 & 0.452 & 0.502 \\
\hline \multirow[t]{6}{*}{ Korea, Rep. of } & $r=0$ & 0.991 & 191.722 & $0.000^{* \star}$ & 93.856 & $0.000^{* *}$ \\
\hline & $r<=1$ & 0.898 & 97.866 & $0.000^{* *}$ & 45.583 & $0.001^{* *}$ \\
\hline & $r<=2$ & 0.721 & 52.283 & $0.018^{*}$ & 25.539 & 0.089 \\
\hline & $r<=3$ & 0.530 & 26.743 & 0.108 & 15.099 & 0.282 \\
\hline & $r<=4$ & 0.330 & 11.644 & 0.175 & 8.011 & 0.378 \\
\hline & $r<=5$ & 0.166 & 3.633 & 0.057 & 3.633 & 0.057 \\
\hline \multirow[t]{6}{*}{ PRC } & $r=0$ & 0.846 & 142.611 & $0.000^{* *}$ & 58.043 & $0.000^{* *}$ \\
\hline & $r<=1$ & 0.735 & 84.568 & $0.002^{* *}$ & 41.214 & $0.006^{* *}$ \\
\hline & $r<=2$ & 0.454 & 43.354 & 0.124 & 18.744 & 0.435 \\
\hline & $r<=3$ & 0.301 & 24.610 & 0.176 & 11.109 & 0.636 \\
\hline & $r<=4$ & 0.262 & 13.501 & 0.098 & 9.421 & 0.253 \\
\hline & $r<=5$ & 0.123 & 4.080 & 0.043 & 4.080 & 0.043 \\
\hline \multirow[t]{6}{*}{ US } & $r=0$ & 0.981 & 229.564 & $0.000^{* \star}$ & 87.655 & $0.000^{* *}$ \\
\hline & $r<=1$ & 0.923 & 141.909 & $0.000^{* *}$ & 56.528 & $0.000^{* *}$ \\
\hline & $r<=2$ & 0.802 & 85.382 & $0.000^{* *}$ & 35.660 & $0.004^{* *}$ \\
\hline & $r<=3$ & 0.707 & 49.721 & $0.000^{* *}$ & 27.017 & $0.007^{* *}$ \\
\hline & $r<=4$ & 0.488 & 22.704 & $0.004^{\star *}$ & 14.722 & $0.042^{*}$ \\
\hline & $r<=5$ & 0.304 & 7.982 & $0.005^{\star *}$ & 7.982 & $0.005^{* *}$ \\
\hline
\end{tabular}

Note: *denotes significance at the $5 \%$ level and ${ }^{* *}$ denotes significance at the $1 \%$ level. 
Table 3: Empirical Results

\begin{tabular}{|c|c|c|c|c|c|c|c|c|c|}
\hline Country & Variable & C.E. & S.E. & t-statistic & Country & Variable & C.E. & S.E. & t-statistic \\
\hline \multirow{5}{*}{$\begin{array}{l}\text { Germany } \\
(n=23)\end{array}$} & $w$ & 3.836 & 6.818 & 0.563 & \multirow{5}{*}{$\begin{array}{l}\text { PRC } \\
(n=32)\end{array}$} & $w$ & 0.336 & 1.579 & 0.213 \\
\hline & $r$ & 0.473 & 0.138 & $3.429^{* *}$ & & $r$ & 0.019 & 0.028 & 0.661 \\
\hline & $A$ & -2.396 & 1.840 & -1.303 & & $A$ & -1.604 & 0.359 & $-4.464^{* *}$ \\
\hline & $\mathrm{p}_{\mathrm{oil}}$ & -0.055 & 0.418 & -0.131 & & $\mathrm{p}_{\text {oil }}$ & -0.448 & 0.180 & $'-2.487^{*}$ \\
\hline & Constant & 26.689 & 18.783 & 1.421 & & Constant & 24.247 & 3.673 & ‘6.602** \\
\hline \multirow{5}{*}{$\begin{array}{l}\text { Japan } \\
(n=23)\end{array}$} & $w$ & 1.938 & 1.722 & 1.126 & \multirow{5}{*}{$\begin{array}{l}\text { US } \\
(n=23)\end{array}$} & $w$ & 2.565 & 1.631 & 1.573 \\
\hline & $r$ & 0.501 & 0.071 & $7.042^{\star *}$ & & $r$ & 0.307 & 0.063 & $4.7882^{\star *}$ \\
\hline & $\mathrm{e}$ & -1.319 & 0.879 & -1.501 & & e & -1.283 & 0.518 & $-2.476^{\star}$ \\
\hline & A & 0.122 & 0.212 & 0.576 & & A & -0.907 & 0.100 & $-9.076^{* *}$ \\
\hline & $\mathrm{p}_{\text {oil }}$ & -0.715 & 0.186 & $-3.846^{\star *}$ & & $\mathrm{p}_{\mathrm{oil}}$ & 0.418 & 0.162 & $2.577^{*}$ \\
\hline \multirow{6}{*}{$\begin{array}{l}\text { Korea, } \\
\text { Rep. of } \\
(n=22)\end{array}$} & $r$ & 0.012 & 0.020 & 0.615 & & & & & \\
\hline & e & -1.889 & 0.466 & $-4.054^{\star *}$ & & & & & \\
\hline & A & -0.312 & 0.051 & $-6.147^{* *}$ & & & & & \\
\hline & $\mathrm{p}_{\mathrm{oil}}$ & -0.038 & 0.173 & -0.219 & & & & & \\
\hline & Constant & 15.111 & 2.060 & $7.334^{\star *}$ & & & & & \\
\hline & \multicolumn{3}{|c|}{ Adjusted R squared: } & 0.973 & & & & & \\
\hline
\end{tabular}

Note: *denotes significance at the $5 \%$ level and ** denotes significance at the $1 \%$ level.

\subsection{Regression Results}

The results for fully modified ordinary least squares (FMOLS) are summarized in Table 3. Several key findings emerged. First, the coefficients for wage $\left(w_{t}\right)$ gave positive results. However, t-statistics were not statistically significant for any of the countries. This suggests that the solar module price industry is not labor-intensive. This leads to the assumption that the market competitiveness of Chinese solar module producing companies was not supported by the low wage rate. Next, interest rate $\left(r_{t}\right)$ has a statistically significant impact on solar module price for Germany, Japan, and the United States. The coefficients were $0.473,0.501$, and 0.307 . A $1 \%$ increase in real interest rate results in a less than $1 \%$ increase in solar module prices. This is consistent with the assumption that solar module industry is capital-intensive. Exchange rate $\left(e_{t}\right)$ has a statistically significant impact on solar module prices in Germany, the Republic of Korea, and the United States. The coefficients were -6.486 , -1.889 , and -1.283 . A $1 \%$ increase in the real effective exchange rate results in an approximately $1 \%$ price decrease in the Republic of Korea and the United States and a $6 \%$ price decrease in Germany. This suggests that as the national currency becomes stronger, the material import costs decline and therefore solar module prices. Furthermore, an increase in the real effective exchange rate decreases oil prices, leading to a decline in solar module prices as substitute goods. Knowledge stock $\left(A_{t}\right)$ has a statistically significant impact on solar module price for the PRC, the Republic of Korea, and the United States. The coefficients were $-1.604,-0.312$, and -0.907 . A $1 \%$ increase in knowledge stock leads to an approximately $1 \%$ decline in solar module prices. This suggests that government investment in solar photovoltaic R\&D expenditure has a positive effect on solar module manufacturing efficiency. Oil price $\left(p_{\text {oil }}\right)$ has a statistically significant impact on solar module prices in the PRC, Japan, and the United States. The coefficients were $-0.448,-0.715$, and 0.418 . The type of influence differs among countries. The coefficients for the PRC and Japan took negative figures. This suggests that a rise in oil price increased future demand for renewable energy, which led to an increase in investment into renewable technology, 
thereby resulting in a price reduction in solar modules through technological advances. This is consistent with the results from past researches that suggested that a decline in oil prices led to renewable technology advances. Meanwhile, the coefficient for the United States takes a positive value. This is because the energy substitution rate between renewable energies and crude oils is high in the United States.

\section{CONCLUSION AND POLICY IMPLICATIONS}

In this paper, we have examined the influence of wage, interest rate, exchange rate, R\&D expenditure, and oil price on the price of solar modules for five major solar module producing countries. As precedent works focused mainly on the supply side factor of the economy, we have assumed that the consideration of potential economic factors would give us new insights into the mechanism surrounding the recent cost reduction in solar modules. We have constructed a solar module pricing model and conducted a fully modified OLS (FMOLS) to estimate the influence of each factor. Our empirical analysis results gave several findings concerning the solar module pricing mechanism. Wage $(w)$ and interest rate $(r)$ have a positive correlation with solar module prices $\left(p_{\text {solar }}\right)$, while exchange rate $(e)$, knowledge stock $(A)$, and oil price $\left(p_{\text {oil }}\right)$ have a negative correlation with solar module prices $\left(p_{\text {solar }}\right)$. There are several solar energy policy recommendations that can be made based on these findings.

First, government must expand channels for renewable energy funding. As renewable industries are high-tech, the influence that capital cost has on technology price is significant. Government efforts to provide industries with low-interest finance will accelerate renewable business. There have been many attempts to lower interest rates for renewable energy technology to accelerate growth in the green technology market. For example, top solar module producing countries such as Malaysia and the Republic of Korea have started what is called green technology financing, which enables renewable energy companies to loan money at a low interest rate. Similarly, there are reports from REN21 (2017) that state that the role of third-party financing may also become strong in the solar energy industry. In the United States, the development of third-party financing has become strong and IEA-PVPS assumes that the lower capital costs driven by these parties have contributed to new installations of solar systems in recent years. These past attempts at lowering interest rates for renewable energy loans will be effective in further reducing prices for solar modules as well as enhancing solar energy installation growth. Therefore, the government must lower interest rates for solar module industry to be able to finance manufacturing.

Second, government must expand R\&D expenditures toward renewable energy technology. The technological advancements acquired through research and development enhance module performance efficiency, thereby reducing cost. Therefore, government policies aimed at increasing R\&D expenditure will be an effective procedure for expanding the installation of renewable energies. However, the differences in environmental regulations and the objectives of R\&D expenditure will have different effects on solar module price. Therefore, specifying the objective of R\&D will be necessary to acquire the expected result of price reduction. Moreover, the influence of corporate R\&D expenditure was not taken into consideration due to a lack of coverage in solar industry surveys. If the influence of corporate R\&D expenditure on solar module price is strong, the exclusion of the series will have a critical impact on the analysis results. Therefore, using corporate R\&D expenditure as an independent variable may give us a better understanding of the role of solar R\&D in reducing technology costs. 


\section{REFERENCES}

Arrow, K. J. (1962). The economic implications of learning by doing. The Review of Economic Studies, 29(3), 155-173. Retrieved 1 19, 2018, from http://www.jstor.org/stable/2295952?seq=1\#page_scan_tab_contents

Bahk, B. H., and Gort, M. (1993). Decomposing learning by doing in new plants. Journal of Political Economy, 101(4), 561-583.

Barreto, L., and Kypreos, S. (2004). Endogenizing R\&D and market experience in the "bottom-up" energy-systems ERIS model. Technovation, 24(8), 615-629. doi:https://doi.org/10.1016/S0166-4972(02)00124-4

Barreto, L., Kypreos, S., Capros, P., and Messener, S. (2000). ERIS: a model prototype with endogenized technological change. International Journal of Global Energy Issues, 14(1/2/3/4), 347-397.

Bloomberg. (2017). Global trends in renewable energy investment 2016. Retrieved 1 19, 2018, from http://fs-unep-centre.org/sites/default/files/publications/ globaltrendsinrenewableenergyinvestment2016lowres_0.pdf

Bruegel. (2017). Real effective exchange rates for 178 countries: a new database. Retrieved from http://bruegel.org/publications/datasets/real-effective-exchangerates-for-178-countries-a-new-database/

Brunnschweiler, C. N. (2009). Finance for renewable energy: an empirical analysis of developing and transition economies. Retrieved 31 January 2018, from http://doc.rero.ch/record/303054/files/S1355770X1000001X.pdf

Cheon, A., and Urpelainen, J. (2012). Oil prices and energy technology innovation: an empirical analysis. Global Environmental Change, 22(2), 407-417.

Glachant, M., Meniere, Y., and Arnaud de la Tour. (2013). Predicting the cost of photovoltaic solar modules in 2020 using experience curve models. Energy, 62(C), 341-348.

Hayamizu, S., Furubayashi, T., and Nakata, T. (2014). Quantification of technological learning by R\&D and its application for renewable energy technologies. Transactions of the JSME, 80(811), TEP0042. doi:https://doi.org/10.1299/ transjsme.2014tep0042

IEA. (2017). Key world energy statistics. Retrieved 4 April 2018, from https://www.iea.org/publications/freepublications/publication/KeyWorld2017.pdf

IEA-PVPS. (1998). Trends in PV Power Applications in selected IEA countries between 1992 and 1997. Retrieved 19 January 2018, from http://www.iea-pvps.org/ fileadmin/dam/public/report/statistics/tr_1998.pdf

(1999). Trends in Photovoltaic Applications in selected IEA Countries Between 1992 and 1998. Retrieved 18 January 2018, from http://www.iea-pvps.org/ fileadmin/dam/public/report/statistics/tr_1998.pdf

. (2000). Trends in Photovoltaic Applications in selected IEA countries between 1992 and 1999. Retrieved 19 January 2018, from http://www.iea-pvps.org/ fileadmin/dam/public/report/statistics/tr_1999.pdf

(2001). Trends in Photovoltaic Applications in selected IEA countries between 1992 and 2000. Retrieved 19 January 2018, from http://www.iea-pvps.org/ fileadmin/dam/public/report/statistics/tr_2000.pdf 
(2002). Trends in Photovoltaic Applications in selected IEA countries between 1992 and 2001. Retrieved 19 January 2008, from http://www.iea-pvps.org/ fileadmin/dam/public/report/statistics/tr_2001.pdf

. (2003). Trends in Photovoltaic Applications Survey report of selected IEA countries between 1992 and 2002. Retrieved 19 January 2018, from http://www.iea-pvps.org/fileadmin/dam/public/report/statistics/tr_2002.pdf

(2004). Trends in Photovoltaic Applications Survey report of selected IEA countries between 1992 and 2003. Retrieved 19 January 2018, from http://www.iea-pvps.org/fileadmin/dam/public/report/statistics/tr_2003.pdf

. (2005). Trends in Photovoltaic Applications Survey report of selected IEA countries between 1992 and 2004. Retrieved 19 January 2018, from http://www.iea-pvps.org/fileadmin/dam/public/report/statistics/tr_2004.pdf

. (2006). Trends in Photovoltaic Applications Survey report of selected IEA countries between 1992 and 2005. Retrieved 19 January 2018, from http://www.iea-pvps.org/fileadmin/dam/public/report/statistics/tr_2005.pdf

. (2007). Trends in Photovoltaic Applications Survey report of selected IEA countries between 1992 and 2006. Retrieved 19 January 2018, from http://www.iea-pvps.org/fileadmin/dam/public/report/statistics/tr_2006.pdf

. (2008). Trends in Photovoltaic Applications Survey report of selected IEA countries between 1992 and 2007. Retrieved 19 January 2018, from http://www.iea-pvps.org/fileadmin/dam/public/report/statistics/tr_2007.pdf

(2009). Trends in Photovoltaic Applications Survey report of selected IEA countries between 1992 and 2008. Retrieved 19 January 2018, from http://www.iea-pvps.org/fileadmin/dam/public/report/statistics/tr_2008.pdf

(2010). Trends in Photovoltaic Applications Survey report of selected IEA countries between 1992 and 2009. Retrieved 19 January 2018, from http://www.iea-pvps.org/fileadmin/dam/public/report/statistics/tr_2009_neu.pdf

. (2011). Trends in Photovoltaic Applications Survey report of selected IEA countries between 1992 and 2010. Retrieved 19 January 2018, from http://www.iea-pvps.org/fileadmin/dam/public/report/statistics/tr_2010_low.pdf

. (2012). Trends in Photovoltaic Applications Survey report of selected IEA countries between 1992 and 2011. Retrieved 19 January 2018, from http://www.iea-pvps.org/fileadmin/dam/public/report/statistics/tr_2011.pdf

(2013). Trends in Photovoltaic Applications 2013. Retrieved 19 January 2018, from http://www.iea-pvps.org/fileadmin/dam/public/report/statistics/

FINAL_TRENDS_v1.02.pdf

. (2014). PVPS report - snapshot of global PV 1992-2013. Retrieved from http://www.iea-pvps.org/fileadmin/dam/public/report/statistics/PVPS_report__A_Snapshot_of_Global_PV_-_1992-2013_-_final_3.pdf

(2014). Trends in Photovoltaic Applications 2014. Retrieved 19 January 2018, from http://www.iea-pvps.org/fileadmin/dam/public/report/statistics/ IEA_PVPS_Trends_2014_in_PV_Applications_-_Ir.pdf

(2015). Trends in Photovoltaic Applications 2015. Retrieved 19 January 2018, from http://www.iea-pvps.org/fileadmin/dam/public/report/national/IEA-PVPS__Trends_2015_-_MedRes.pdf 
(2016). National Survey Report of PV Power Applications in Korea 2015.

Retrieved 22 January 2018, from http://www.iea-pvps.org/index.php?id

$=9 \&$ elD=dam_frontend_push\&doclD=3644

. (2016). Trends in Photovoltaic Applications 2016. Retrieved 19 January 2018, from http://www.iea-pvps.org/fileadmin/dam/public/report/national/

Trends_2016_-_mr.pdf

IRENA. (2012). Renewable Energy Technologies: Cost Analysis Series. 1(4/5).

Retrieved 31 January 2018, from https://www.irena.org/documentdownloads/ publications/re_technologies_cost_analysis-solar_pv.pdf

Kimura, K., and Zissler, R. (2016). Comparing prices and costs of solar PV in Japan and Germany. 1(4/5). Retrieved 31 January 2018, from https://www.renewableei.org/en/images/pdf/20160331/JREF_Japan_Germany_solarpower_costcompa rison_en.pdf

McDonald, A., and Scrattenholzer, L. (2000). Learning rates for energy technologies. Energy Policy, 29(4), 255-261.

Messener, S. (1998). IIASA Maquette Prototype on Endogenized Technological Learning.

Miketa, A., and Schrattenholzer, L. (2004). Experiments with a methodology to model the role of R\&D expenditures in energy technology learning processes: first results. Energy Policy, 32(15), 1679-1692.

Ministry of the Environment. (2015). Oushuushuyoukoku ni okeru koteikakakukaitoriseido no hensendoukouchousa [Transition survey on feed in tariff policies in major European countries]. Retrieved 5 February 2018, from https://www.env.go.jp/earth/report/h27-01/ref04_3.pdf

Monnin, P. (2015). The impact of interest rates on electricity production costs. Retrieved 31 January 2018, from https://www.cepweb.org/wp-content/ uploads/CEP_DN_Interest_Rates_Energy_Prices.pdf

Neij, L., Anderson, P. D., and Durstewitz, M. (1997). The use of experience curves for assessing energy policy programs. Energy Policy, 25(13), 1099-1107.

Nemet, G. F. (2005). Beyond the learning curve: factors influencing cost reductions in photovoltaics. Energy Policy, 34(17), 3218-3232. doi:https://doi.org/10.1016/ j.enpol.2005.06.020

Nemet, G., and Arnulf, G. (2012). Sources and consequences of knowledge depreciation. Historical case studies of energy technology innovation. Historical Case Studies of Energy Technology Innovation, 24. doi:https://doi.org/10.1017/ CBO9781139150880.014

OECD. (2018). Labour: Hourly Earning. Retrieved 31 January 2018, from http://dx.doi.org/10.1787/data-00044-en

Papandreou, A., and Ruzzenenti, F. (2015). Effects of fossil fuel prices on the transition to a low-carbon economy. Working papers wpaper89, Financialisation, Economy, Society \& Sustainable Development (FESSUD) Project.

Phillips, P. C., and Hansen, B. E. (1990). Statistical inference in instrumental variables regression with I(1) processes. The Review of Economic Studies, 57(1), 99-125.

Pillai, U. (2014). Cost reduction in crystalline silicon solar modules. doi:http://dx.doi.org/ $10.2139 /$ ssrn.2259155 
(2015). Drivers of cost reduction in solar photovoltaics. Energy Economics, 50(C), 286-293. Retrieved 19 January 2018, from https://www.albany.edu/ econ_technology/unni_pillai/pubs/solar_price_cost_reduction_energy_economic s_rev2_2.pdf

REN21. (2017). Renewables 2017 global status report. Retrieved 4 April 2018, from http://www.ren21.net/wp-content/uploads/2017/06/17-8399_GSR_2017_ Full_Report_0621_Opt.pdf

Renewable Energy Institute. (2017). Feed-in tariffs in Japan: five Years of achievements and future challenges. Retrieved 5 February 2018, from https://www.renewable-ei.org/en/activities/reports/img/pdf/20170810/ REI_Report_20170908_FIT5years_Web_EN.pdf

Sallenave, J.-P. (1985). The uses and abuses of experience curves. Long Range Planning, 18(1), 64-72. doi:https://doi.org/10.1016/0024-6301(85)90180-3

Schaeffer, G., Seebregts, A., Beurskens, L., Moor, H., Alsema, E., Sark, W., . . . Zuccaro, C. (2004). Learning from the sun: analysis of the use of experience curves for energy policy purposes: the case of photovoltaic energy. Final report of the PHOTEX Project. Report ECN DEGO: ECN-C-04-035, ECN Renewable Energy in the Built Environment. Retrieved 131, 2018, from https://www.ecn.nl/ docs/library/report/2004/c04035.pdf

Shimamoto, M., Kokubu, K., and Ueta, K. (2017, 8 30). Guri-n Inobe-shon 'Green Innovation'. Tokyo: Chuo-keizaisha.

Solar Power Europe. (2014). Global market outlook for solar power 2014-2018. Retrieved 19 January 2018, from http://www.solarpowereurope.org/fileadmin/ user_upload/Publications/EPIA_Global_Market_Outlook_for_Photovoltaics_201 4-2018_-_Medium_Res.pdf

Solar Power Europe. (2015). Global market outlook for solar power 2015-2019. Retrieved 19 January 2018, from http://www.solarpowereurope.org/fileadmin/ user_upload/documents/Publications/Global_Market_Outlook_2015_2019_Ir_v23.pdf

(2016). Global market outlook for solar power 2016-2020. Retrieved 19 January 2018, from http://www.solareb2b.it/wp-content/uploads/ 2016/06/SPE_GMO2016_full_version.pdf

Taghizadeh-Hesary, F., and Yoshino, N. (2014). Monetary policies and oil price determination: an empirical analysis. OPEC Energy Review, 38(1), 1-20. doi:https://doi.org/10.1111/opec.1202

(2015). Macroeconomic effects of oil price fluctuations on emerging and developed economies in a model incorporating monetary variables. Economics and Policy of Energy and the Environmental, 2, 51-75. doi:https://doi.org/ 10.3280/EFE2015-002005

Taghizadeh-Hesary, F., Yoshino, N., Abdoli, G., and Farzinvash, A. (2013). An estimation of the impact of oil shocks on crude oil exporting economies and their trade partners. Frontiers of Economics in China, 8(4), 571-591. doi:https://doi.org/10.3868/s060-002-013-0029-3

Taghizadeh-Hesary, F., Yoshino, N., Adabi, M., and Farboudmanesh, R. (2016). The response of macro variables of emerging and developed oil importers to oil price movements. Journal of the Asia Pacific Economy, 21(1), 91-102. doi:https://doi.org/10.1080/13547860.2015.1057955 
Terrado, E., Mendis, M., and Fitzgerald, K. (1988). Impact of lower oil prices on renewable energy technologies. Retrieved 31 January 2018, from http://documents.worldbank.org/curated/en/829911468765911625/pdf/ multi-page.pdf

Watanabe, C., Nagamatsu, A., and Griffy-Brown, C. (2003). Behavior of technology in reducing prices of innovative goods - an analysis of the governing factors of variance of PV module prices. Technovation, 23(5), 423-436. doi:https://doi.org/ 10.1016/S0166-4972(01)00121-3

Wong, S. L., Chia, W.-M., and Chang, Y. (2013). Energy consumption and energy R\&D in OECD: perspectives from oil prices and economic growth. Energy Policy, 62, $1581-1590$.

World Bank. (2018). GDP deflator (base year varies by country) | Data. Retrieved 31 January 2018, from http://api.worldbank.org/v2/en/indicator/ NY.GDP.DEFL.ZS?downloadformat=excel

Wright, T. P. (1936). Factors affecting the cost of airplanes. Journal of the Aeronautical Sciences, 3, 122-128. doi:https://doi.org/10.2514/8.155

Yoshino, N., and Taghizadeh-Hesary, F. (2014). Monetary policies and oil price fluctuations following the subprime mortgage crisis. Int. J. Monetary Economics and Finance, 7(3), 157-174. doi:https://doi.org/10.1504/IJMEF.2014.066482

Youah. (2013). Learning by doing effect from solar photovoltaic RD\&D. Retrieved 31 January 2018, from http://eneken.ieej.or.jp/3rd_IAEE_Asia/pdf/ paper/068p.pdf 